\title{
Protein composition affects variation in coagulation properties of buffalo milk
}

\author{
V. Bonfatti, ${ }^{*}$ M. Gervaso, ${ }^{*}$ R. Rostellato, ${ }^{*}$ A. Coletta, $†$ and P. Carnier*1 \\ *Department of Comparative Biomedicine and Food Science (BCA), University of Padova, viale dell'Università 16, 35020, Legnaro, Padova, Italy \\ †Associazione Nazionale Allevatori Specie Bufalina (ANASB), via Petrarca 42-44, 81100 Caserta, Italy
}

\begin{abstract}
The aim of this study was to investigate the effects exerted by the content of casein and whey protein fractions on variation of $\mathrm{pH}$, rennet-coagulation time (RCT), curd-firming time $\left(\mathrm{K}_{20}\right)$, and curd firmness of Mediterranean buffalo individual milk. Measures of milk protein composition and assessment of genotypes at CSN1S1 and CSN3 were obtained by reversed-phase HPLC analysis of 621 individual milk samples. Increased content of $\alpha_{S_{1}}$-casein $(\mathrm{CN})$ was associated with delayed coagulation onset and increased $\mathrm{K}_{20}$, whereas average $\mathrm{pH}, \mathrm{RCT}$, and $\mathrm{K}_{20}$ decreased when $\beta-\mathrm{CN}$ content increased. Milk with low $\kappa-\mathrm{CN}$ content exhibited low $\mathrm{pH}$ and $\mathrm{RCT}$ relative to milk with high content of $\kappa$-CN. Increased content of glycosylated $\kappa-\mathrm{CN}$ was associated with unfavorable effects on RCT. Effects of milk protein composition on curd firmness were less important than those on $\mathrm{pH}, \mathrm{RCT}$, and $\mathrm{K}_{20}$. Likely, this occurred as a consequence of the very short RCT of buffalo milk, which guaranteed a complete strengthening of the curd even in the restricted 31 min time of analysis of coagulation properties and for samples initially showing soft curds. Effects of CSN1S1-CSN3 genotypes on coagulation properties were not to be entirely ascribed to existing variation in milk protein composition associated with polymorphisms at CSN1S1 and CSN3 genes. Although the role of detailed milk protein composition in variation of cheese yield needs to be further investigated, findings of this study suggest that modification of the relative content of specific CN fractions can relevantly influence the behavior of buffalo milk during processing.
\end{abstract}

Key words: buffalo, milk coagulation, casein, whey protein

\section{INTRODUCTION}

Renneting properties of milk are crucial aspects because coagulation is the basis of the cheese-making process. Although several factors affecting renneting

Received October 31, 2012.

Accepted March 3, 2013.

${ }^{1}$ Corresponding author: paolo.carnier@unipd.it properties of buffalo milk have been investigated (Potena et al., 2001; Ariota et al., 2007; Cecchinato et al., 2012), knowledge of the major sources of variation of buffalo milk coagulation properties (BMCP) is still scarce. The effects of the composition of the 6 major milk proteins $\left(\alpha_{\mathrm{S}^{-}} \mathrm{CN}, \alpha_{\mathrm{S} 2^{-}} \mathrm{CN}, \beta-\mathrm{CN}\right.$, and $\kappa$-CN, together with the 2 whey proteins $\alpha$-LA and $\beta-\mathrm{LG}$ ) on $\mathrm{BMCP}$ have never been investigated in detail, although different $\kappa-\mathrm{CN}$ patterns seem to be responsible for variation of coagulation time (Addeo et al., 1984) and cheese yield (Ariota et al., 2009).

Recently, the effects of CN composite genotypes on $\mathrm{BMCP}$ and those of some nongenetic factors on detailed protein composition have been described (Bonfatti et al., 2012a,b). In addition, the protein composition of Mediterranean buffalo milk, namely the percentages of $\alpha_{\mathrm{S}_{1}} \mathrm{CN}, \alpha_{\mathrm{S}_{2}} \mathrm{CN}$, and $\kappa_{-} \mathrm{CN}$ in total casein and the percentage ratio of glycosylated- $\kappa-\mathrm{CN}$ to $\kappa-\mathrm{CN}$, has been reported to be influenced by $\mathrm{CN}$ genotypes (Bonfatti et al., 2012c). Associations of specific genotypes at the milk protein genes with the variation in the relative content of the major protein fractions have been indicated to be responsible for the effects of those genotypes on the renneting properties of cow and goat milk (Fox and McSweeney, 2003). As for other dairy species, protein composition may play a role in variation of technological properties of buffalo milk. The aim of this study was to investigate the effects of milk protein composition on variation in $\mathrm{pH}$ and $\mathrm{BMCP}$ in Mediterranean water buffalo.

\section{MATERIALS AND METHODS}

\section{Milk Sampling}

Composite milk samples of 2 consecutive evening and morning milkings were collected from October 2010 to April 2011 for 621 Mediterranean water buffaloes reared in 15 farms (Campania region, southern Italy). Only 1 sample was collected for each animal and milk sampling occurred once per herd. Each individual sample was partitioned into 2 subsamples that were frozen immediately after collection and stored at $-20^{\circ} \mathrm{C}$ until transfer to the milk laboratory. Samples were stored in dry ice during the transfer and, at arrival, 1 subsample 
per animal was thawed at $35^{\circ} \mathrm{C}$ for $\mathrm{BMCP}$ analysis, whereas the other was preserved at $-40^{\circ} \mathrm{C}$ until HPLC analysis for the assessment of milk protein composition.

\section{Milk Coagulation Properties}

Although milk freezing is undesirable because it may originate significant modification of the $\mathrm{CN}$ micelle structure and composition (i.e., separation of $\beta-\mathrm{CN}$ and other $\mathrm{CN}$ fractions and release of colloidal calcium phosphate), with unfavorable effects on milk coagulation properties, freezing was necessary to preserve the samples during the transfer from the farms to the laboratory (which took approximately $48 \mathrm{~h}$ ) and to avoid proteolysis and its effects on the quantification of milk protein fractions.

To ensure the reequilibrium of $\mathrm{CN}$ micelles, after thawing, milk samples were kept at room temperature for $2 \mathrm{~h}$ before performing the measurement of BMCP. Milk coagulation properties were measured by a computerized renneting meter (CRM-48; Polo Trade, Monselice, Italy), which is based on the swing of a pendulum driven by an electromagnetic field. Variations in the electromagnetic field are recorded during the milk coagulation process. After rennet addition, coagulation takes place and the swing of the pendulum becomes smaller because of the enhanced curd firmness. Details on the equipment used to assess milk coagulation properties have been reported by Dal Zotto et al. (2008), including repeatability and reproducibility of measures.

Samples $(10 \mathrm{~mL})$ were preheated at $35^{\circ} \mathrm{C}$ and 200 $\mu \mathrm{L}$ of rennet (Hansen standard 160, $80 \%$ chymosin, 1:14,900; Pacovis Amrein AG, Bern, Switzerland) diluted to $1.6 \%$ ( $\mathrm{vol} / \mathrm{vol})$ in distilled water was added to milk. One measure of rennet-coagulation time (RCT), curd-firming time $\left(\mathbf{K}_{\mathbf{2 0}}\right)$, and curd firmness at $30 \mathrm{~min}$ after rennet addition $\left(\mathbf{A}_{\mathbf{3 0}}\right)$ was obtained per each sample. Measurement of milk pH (pH-Burette 24; Crison Instruments SA, Barcelona, Spain) was carried out immediately before BMCP analysis.

\section{Milk Protein Composition and Genotyping for CN Genes}

Contents of $\alpha_{\mathrm{S}^{-}} \mathrm{CN}, \alpha_{\mathrm{S} 2^{-}} \mathrm{CN}, \beta-\mathrm{CN}, \gamma-\mathrm{CN}$, glycosyl-

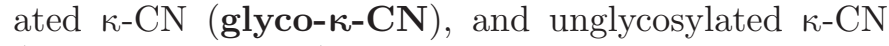
(glyco-free- $\kappa-\mathbf{C N}$ ), $\alpha-\mathrm{LA}$, and $\beta$-LG were measured by reversed-phase HPLC. A detailed description of the procedures for HPLC analysis of buffalo milk protein composition can be found in Bonfatti et al. (2008) and Bonfatti et al. (2013). Total CN content (TCN; g/L) was computed as the sum of $\alpha_{\mathrm{S}^{-}} \mathrm{CN}, \alpha_{\mathrm{S} 2}-\mathrm{CN}, \beta-\mathrm{CN}$, $\gamma-\mathrm{CN}$, and total $\kappa$-CN (i.e., the sum of glyco- $\kappa-\mathrm{CN}$ and glyco-free-k-CN). Total whey protein content
(WH; g/L) was calculated as the sum of $\alpha-\mathrm{LA}$ and $\beta-\mathrm{LG}$ content. As the frequency distribution of $\gamma$-CN was skewed, a logarithmic transformation of $\gamma-\mathrm{CN}$ was computed and used in the statistical analysis. Assessment of genotypes of buffaloes at CSN1S1 and CSN3 was also obtained by HPLC (Bonfatti et al., 2013).

\section{Statistical Analysis}

Effects of milk protein composition and CN genotypes on variation of $\mathrm{pH}$ and BMCP were estimated using different linear models (see Appendix Table A1 for a description of models). These models aimed to investigate initially the effects of groups of protein fractions (casein and whey protein), then those of protein fractions $\left(\alpha_{\mathrm{S}^{-}} \mathrm{CN}, \alpha_{\mathrm{S} 2}-\mathrm{CN}, \beta-\mathrm{CN}, \gamma-\mathrm{CN}, \kappa-\mathrm{CN}\right.$, glyco$\kappa-\mathrm{CN}$, glyco-free- $\kappa-\mathrm{CN}, \alpha-\mathrm{LA}$, and $\beta-\mathrm{LG})$, and lastly to assess whether the effects of protein composition were to be ascribed to variation in enzyme efficiency related to milk acidity.

Preliminary analyses evidenced nonlinear effects of some protein fraction contents on BMCP. Hence, the milk content of each protein or group of proteins was classified as follows: class PR - (content $<\bar{x}-\mathrm{SD}$ ), class $\mathrm{PR}--(\bar{x}-\mathrm{SD} \leq$ content $<\bar{x}-0.5 \mathrm{SD})$, class PR0 $(\bar{x}-0.5 \mathrm{SD} \leq$ content $<\bar{x}+0.5 \mathrm{SD})$, class PR+ $(\bar{x}+0.5 \mathrm{SD} \leq$ content $<\bar{x}+\mathrm{SD})$, and class $\mathrm{PR}++$ (content $\geq \bar{x}+\mathrm{SD}$ ).

Additive polygenic effects of the animals or, as an alternative, sire effects were not included in any of the models because reliable pedigree information was not available for all the animals. Indeed, AI is not a common practice in the Italian buffalo population (Rosati and Van Vleck, 2002) and parentage misidentification often occurs (Parlato and Van Vleck, 2012).

Parameters of interest were differences between genotype effects and differences between protein composition class effects, which were computed from model solutions. The marginal posterior densities of parameters of interest, estimated using Bayesian procedures and Gibbs sampling (Sorensen and Gianola, 2002), were used to perform statistical inference. The mean of the marginal posterior density was used as a point estimate of the parameter. From the marginal density, we computed the lower and upper bounds of the $95 \%$ highest posterior density interval and the probability of a parameter of being greater (for positive estimates) or lower (for negative estimates) than 0. Differences between genotype or protein composition class effects were considered to be statistically relevant when such probability was greater than $95 \%$.

All Bayesian analyses were performed using bounded uniform distributions as prior densities for the effects included in the models to indicate vague prior knowl- 
edge about the investigated effects. Marginal posterior densities were estimated using a single chain of 200,000 Gibbs samples with a burn-in of 20,000 iterations and saving samples at 50-iteration intervals. Convergence was checked by visual inspection of the chains.

\section{RESULTS AND DISCUSSION}

Descriptive statistics for BMCP and detailed milk protein composition are reported in Table 1. Average RCT was short and all milk samples coagulated within 22 min after rennet addition. Hence, no record was discarded due to missing information on RCT as a consequence of noncoagulating milk (Cecchinato and Carnier, 2011). Among BMCP measures, $\mathrm{A}_{30}$ was the least variable coagulation property. Descriptive statistics for BMCP and protein composition largely agreed with those of previous studies (Zicarelli, 2004; Ariota et al., 2007).

\section{Effect of Casein and WH on pH and BMCP}

Estimates of the effects of TCN and $\mathrm{WH}$ on $\mathrm{pH}$ and BMCP are reported in Table 2. Because the effect of TCN was estimated at a constant $\mathrm{WH}$ and vice versa, these estimated effects are comparable to those caused by variation in the relative proportions of TCN and $\mathrm{WH}$ in total protein. In agreement with Ikonen et al. (2004), average $\mathrm{pH}$ of milk with the lowest TCN (class $\mathrm{PR}--$ ) was high relative to milk of the remaining TCN classes. Conversely, milk pH was the highest for milk exhibiting the highest WH. Coagulation time of the 2 extreme classes for TCN was similar and consistently shorter than that of classes exhibiting intermediate TCN. When the statistical model accounted for variation in milk $\mathrm{pH}$ (data not presented in tables), coagulation time of class $\mathrm{PR}--$ was comparable to that of intermediate TCN classes. Positive associations between RCT and milk protein content have been reported by Ariota et al. (2007), but no association has been detected in other studies on buffalo milk (Potena et al., 2007; Cecchinato et al., 2012). Also for cow milk, effects exerted by TCN or total protein on variation of RCT are controversial (Bonfatti et al., 2011). A possible explanation for the inconsistent results on the relationship between TCN and RCT might be the relation between rennet enzyme and substrate concentrations. If the enzyme is saturated, the speed of the enzymatic reaction might be lower for high TCN than for low TCN. For very high TCN in milk, the critical level of CN cleavage needed for the onset of gelation might be so high as to delay coagulation. In addition, inconsistent results for the effects of TCN on RCT might also be due to variation in $\mathrm{CN}$ composition or mineral content. On average, $\mathrm{A}_{30}$ was $2.6 \mathrm{~mm}(0.5 \mathrm{SD})$ greater in milk exhibiting the highest TCN than in milk with the lowest TCN. The favorable effect of increased TCN on $\mathrm{A}_{30}$ observed in this study is in agreement with findings of most investigations on buffalo (Potena et al., 2007; Cecchinato et al., 2012), cow (Ikonen et al., 2004; Wedholm et al., 2006; Bonfatti et al., 2011), or goat (Ambrosoli et al., 1988) milk.

Table 1. Descriptive statistics of milk coagulation properties and detailed protein composition of individual milk samples $(\mathrm{n}=621)$ of Mediterranean buffalo milk ${ }^{1,2}$

\begin{tabular}{|c|c|c|c|c|c|}
\hline Trait & Abbreviation & Mean & $\mathrm{CV}, \%$ & $\mathrm{P} 1$ & P99 \\
\hline Rennet-coagulation time, min & $\mathrm{RCT}$ & 8.46 & 37.3 & 3.73 & 21.27 \\
\hline Curd-firming time, min & $\mathrm{K}_{20}$ & 0.98 & 38.2 & 0.50 & 2.28 \\
\hline Curd firmness, mm & $\mathrm{A}_{30}$ & 41.32 & 12.7 & 28.00 & 53.00 \\
\hline $\mathrm{pH}$ & $\mathrm{pH}$ & 6.57 & 1.7 & 6.28 & 6.87 \\
\hline Casein, $^{3} \mathrm{~g} / \mathrm{L}$ & TCN & 49.80 & 11.8 & 37.14 & 63.08 \\
\hline Whey protein, ${ }^{4} \mathrm{~g} / \mathrm{L}$ & WH & 9.64 & 13.6 & 6.67 & 12.95 \\
\hline \multicolumn{6}{|l|}{ Protein fraction } \\
\hline$\alpha_{S_{1}-} \mathrm{CN}, \mathrm{g} / \mathrm{L}$ & $\alpha_{\mathrm{S} 1}-\mathrm{CN}$ & 16.07 & 13.0 & 11.54 & 21.21 \\
\hline$\alpha_{S_{2}}-\mathrm{CN}, \mathrm{g} / \mathrm{L}$ & $\alpha_{\mathrm{S} 2}-\mathrm{CN}$ & 7.99 & 17.5 & 5.01 & 12.22 \\
\hline$\beta-\mathrm{CN}, \mathrm{g} / \mathrm{L}$ & $\beta-\mathrm{CN}$ & 17.70 & 17.4 & 10.96 & 24.21 \\
\hline$\gamma-\mathrm{CN},{ }^{5} \log _{10} \mathrm{~g} / \mathrm{L}$ & $\mathrm{L} \gamma-\mathrm{CN}$ & -1.53 & 33.9 & -2.84 & -0.12 \\
\hline$\kappa-\mathrm{CN},{ }^{6} \mathrm{~g} / \mathrm{L}$ & $\kappa-\mathrm{CN}$ & 7.79 & 11.9 & 5.78 & 10.13 \\
\hline Glycosylated к-CN, g/L & glyco-к-CN & 2.49 & 23.3 & 1.23 & 3.98 \\
\hline Unglycosylated $\kappa-\mathrm{CN}, \mathrm{g} / \mathrm{L}$ & glyco-free- $\kappa-\mathrm{CN}$ & 5.30 & 15.1 & 3.25 & 7.24 \\
\hline$\alpha-\mathrm{LA}, \mathrm{g} / \mathrm{L}$ & $\alpha-\mathrm{LA}$ & 4.19 & 26.9 & 1.89 & 6.97 \\
\hline$\beta-\mathrm{LG}, \mathrm{g} / \mathrm{L}$ & $\beta-\mathrm{LG}$ & 5.45 & 17.3 & 3.52 & 7.99 \\
\hline
\end{tabular}

${ }^{1}$ Contents of all protein fractions were measured by reversed-phase HPLC on skim milk.

${ }^{2} \mathrm{P} 1=1$ st percentile; $\mathrm{P} 99=99$ th percentile.

${ }^{3}$ Casein is the sum of $\alpha_{\mathrm{S}^{-}} \mathrm{CN}, \alpha_{\mathrm{S}^{2}} \mathrm{CN}, \beta-\mathrm{CN}, \gamma-\mathrm{CN}$, and $\kappa-\mathrm{CN}$.

${ }^{4}$ Whey protein is the sum of $\alpha-\mathrm{LA}$ and $\beta$-LG.

${ }^{5} \gamma-\mathrm{CN}=$ logarithmic transformation of $\gamma-\mathrm{CN}$ content.

${ }^{6} \kappa-\mathrm{CN}=$ sum of glycosylated $\kappa-\mathrm{CN}$ and unglycosylated $\kappa-\mathrm{CN}$. 
Table 2. Estimate and 95\% highest posterior density region (HPD95\%) of the effect of casein and whey protein content class relative to the intermediate class $(\mathrm{PR} 0)$ on $\mathrm{pH}$, rennet-coagulation time $(\mathrm{RCT})$, curd-firming time $\left(\mathrm{K}_{20}\right)$, and curd firmness $\left(\mathrm{A}_{30}\right)^{1}$

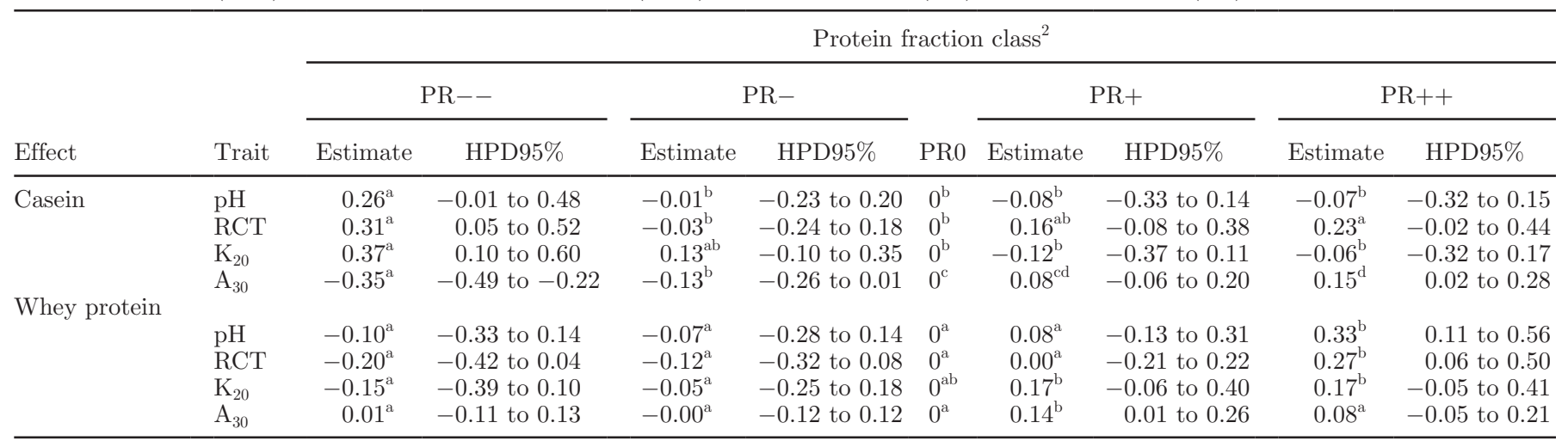

\footnotetext{
${ }^{\mathrm{a}-\mathrm{d}}$ Estimates within a row with different superscripts have a posterior probability greater than $95 \%$ of being different.

${ }^{1}$ Magnitudes of the estimates are expressed in standard deviation units of the trait.

${ }^{2}$ Casein and whey protein contents were classified as follows: class PR -- (content $<\bar{x}-\mathrm{SD}$ ), class PR $-(\bar{x}-\mathrm{SD} \leq$ content $<\bar{x}-0.5 \mathrm{SD})$, class PR0 $(\bar{x}-0.5 \mathrm{SD} \leq$ content $<\bar{x}+0.5 \mathrm{SD})$, class $\mathrm{PR}+(\bar{x}+0.5 \mathrm{SD} \leq$ content $<\bar{x}+\mathrm{SD})$, and class $\mathrm{PR}++($ content $\geq \bar{x}+\mathrm{SD})$.
}

Although only caseins are directly involved in the milk coagulation process and curd formation, the highest WH class exhibited an increased RCT. Such an effect was attributable to the increased $\mathrm{pH}$ associated with this class. We detected no relevant association between $\mathrm{WH}$ and variation of $\mathrm{A}_{30}$. This was partly expected because, during curd formation, aggregated caseins form cross-linked network structures entrapping fat globules and contributing to the strengthening of the curd, whereas WH is lost in the whey.

\section{Effects of Casein Fraction Contents on $\mathrm{pH}$ and $\mathrm{BMCP}$}

Because inherent characteristics of milk protein fractions contribute to variation in size, surface charge, hydrodynamic radius, hydration, and mineral content of the CN micelle, the content of protein fractions is expected to affect the overall structure and properties of the micelle (Fox and McSweeney, 2003). The estimated effects of $\mathrm{CN}$ fraction contents on BMCP are reported in Table 3. Coagulation time and $\mathrm{K}_{20}$ were mainly affected by $\alpha_{\mathrm{S}^{-}} \mathrm{CN}$ and $\beta-\mathrm{CN}$ content, but variations in BMCP associated with $\alpha_{\mathrm{S}_{2}}-\mathrm{CN}, \kappa-\mathrm{CN}$, and $\gamma-\mathrm{CN}$ content class were also observed. Influence of $\mathrm{CN}$ fraction contents on variation in $\mathrm{A}_{30}$ was trivial.

Studies on the role of protein fractions in coagulation of buffalo milk are almost completely lacking, but the primary structure of milk proteins as well as the differential susceptibility of CN fractions to chymosin (ElShibiny and Abd El-Salam, 1977; Addeo et al., 1980; Addeo et al., 1984) is known to be similar in different dairy species (Fox and McSweeney, 2003). Hence, comparisons across species are essential to better elucidate the role of buffalo milk proteins in variation in BMCP.
Content of $\alpha_{S 1}-C N$. Rennet-coagulation time was markedly affected by $\alpha_{\mathrm{S}_{1}}$-CN content. The difference in RCT between class $\mathrm{PR}--$ and $\mathrm{PR}++$ was 0.93 standard deviation units (i.e., almost $3 \mathrm{~min}$ ). These effects persisted, albeit being less intense, when the statistical model accounted for milk pH. For cow milk, reported associations between $\alpha_{\mathrm{S} 1}-\mathrm{CN}$ content or percentage and coagulation time were null (Wedholm et al., 2006) or weakly positive (Bonfatti et al., 2011). However, when variation of $\alpha_{\mathrm{S}^{-}} \mathrm{CN}$ content was large, results were different. Mariani et al. (2001) compared milk renneting properties of heterozygous cows carrying the $\mathrm{G}$ allele at CSN1S1, which is responsible for an impaired content of $\alpha_{S 1}-\mathrm{CN}$, with those of CSN1S1 BB and CSN1S1 BC cows. Low $\alpha_{\mathrm{S1}^{-}} \mathrm{CN}$ milk had a coagulation time $23 \%$ shorter than that of normal milk. Because of existence of null alleles at CSN1S1 and CSN2, which are responsible for the absence of $\alpha_{\mathrm{S1}^{-}} \mathrm{CN}$ and $\beta$-CN, respectively, goat milk represents a valuable model to investigate the effects due to extensive variation in the content of $\mathrm{CN}$ fractions. This is particularly true for animals carrying CSN1S1 null alleles, in which no compensatory synthesis of other casein fractions counterbalances the decreased amount of $\alpha_{\mathrm{S} 1}-\mathrm{CN}$ (Ambrosoli et al., 1988). Similar to that in CSN1S1 G cow milk, goat milk with reduced content of $\alpha_{\mathrm{S}_{1}} \mathrm{CN}$ exhibits short coagulation time relative to milk with normal $\alpha_{\mathrm{S}_{1}} \mathrm{CN}$ content (Ambrosoli et al., 1988; Clark and Sherbon, 2000). Although some authors hypothesized that $\alpha_{\mathrm{S}_{1}} \mathrm{CN}$ delays curd formation by trapping $\mathrm{Ca}^{++}$and decreasing their availability for binding after $\kappa$-CN cleavage, conclusive evidence explaining the association between $\alpha_{\mathrm{S}_{1}} \mathrm{CN}$ content and coagulation time is currently unavailable.

Content of $\boldsymbol{\beta}-\boldsymbol{C N}$. Differences in $\beta$-CN content were, to a great extent, responsible for $\mathrm{pH}$ variation. 
Table 3. Estimate and 95\% highest posterior density region (HPD95\%) of the effect of casein fraction content class relative to the intermediate class $(\mathrm{PR} 0)$ on $\mathrm{pH}$, rennet-coagulation time $(\mathrm{RCT})$, curd-firming time $\left(\mathrm{K}_{20}\right)$, and curd firmness $\left(\mathrm{A}_{30}\right)^{1}$

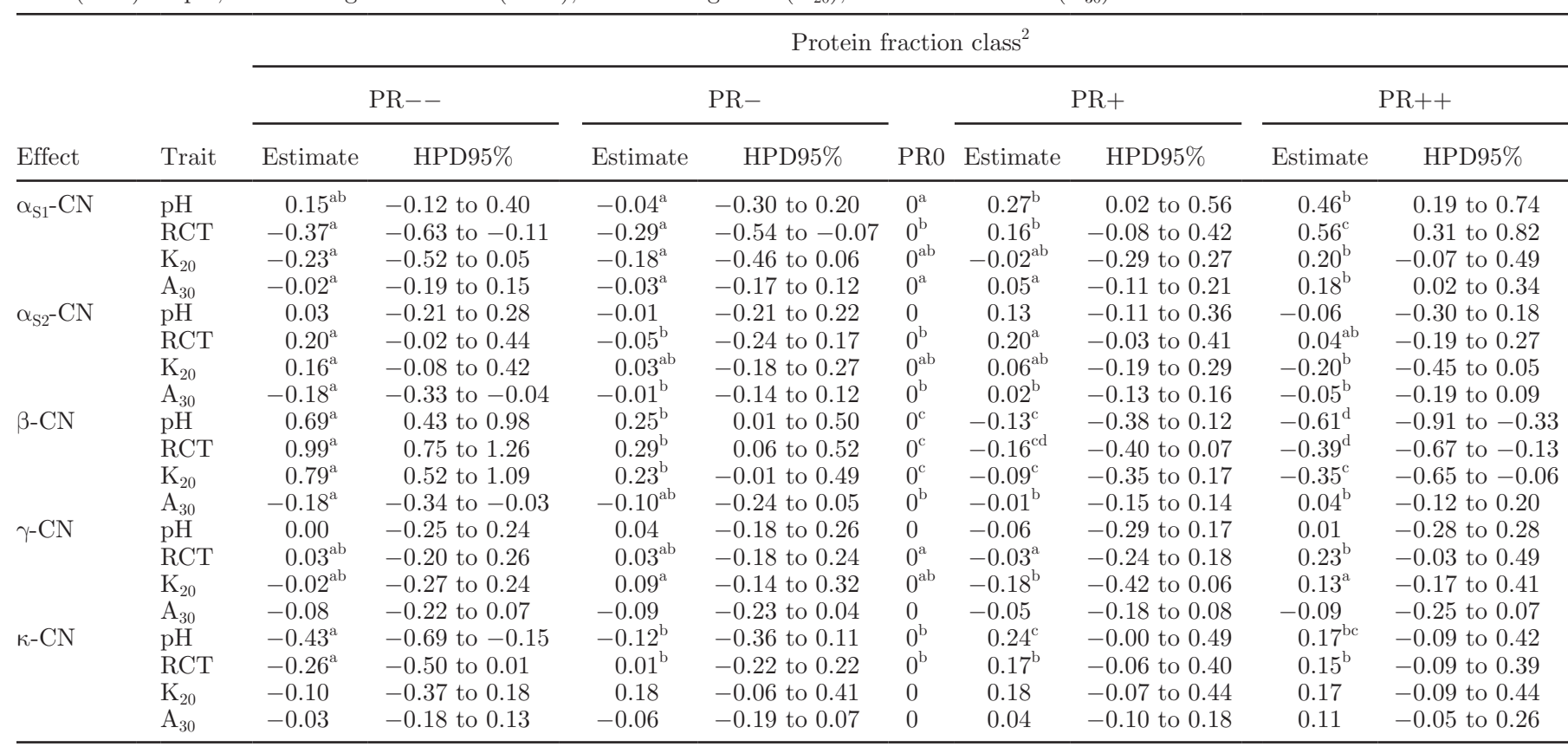

\footnotetext{
${ }^{\mathrm{a}-\mathrm{d}}$ Estimates within a row with different superscripts have a posterior probability greater than $95 \%$ of being different.

${ }^{1}$ Magnitudes of the estimates are expressed in standard deviation units of the trait.

${ }^{2}$ Casein fraction content was classified as follows: class PR $--($ content $<\bar{x}-\mathrm{SD})$, class PR $-(\bar{x}-\mathrm{SD} \leq$ content $<\bar{x}-0.5 \mathrm{SD})$, class PR0 $(\bar{x}$ $-0.5 \mathrm{SD} \leq$ content $<\bar{x}+0.5 \mathrm{SD})$, class $\mathrm{PR}+(\bar{x}+0.5 \mathrm{SD} \leq$ content $<\bar{x}+\mathrm{SD})$, and class $\mathrm{PR}++($ content $\geq \bar{x}+\mathrm{SD})$.
}

Milk $\mathrm{pH}$ of class $\mathrm{PR}++$ for $\beta$-CN content was 1.3 standard deviation units lower than that of class PR--. Milk acidity mainly depends upon the ratio of soluble to colloidal minerals. As protein fractions bind minerals with dissimilar affinity, variation in protein composition is expected to affect milk $\mathrm{pH}$. As an example, at low temperature, the dissociation of $\beta-\mathrm{CN}$ from the $\mathrm{CN}$ micelle causes the solubilization of the colloidal calcium phosphate, which increases milk pH (Raynal and Remeuf, 2000).

Among milk protein fractions, $\beta-\mathrm{CN}$ was the protein exhibiting the most intense effect on variation of $\mathrm{RCT}$ and $\mathrm{K}_{20}$. Class PR-- had longer RCT $(+1.3 \mathrm{SD}$ of the trait) and $\mathrm{K}_{20}(+1.1 \mathrm{SD}$ of the trait) than class PR++. These differences are equivalent to +4 and $+0.4 \mathrm{~min}$ for RCT and $\mathrm{K}_{20}$, respectively. As variation of RCT and $\mathrm{K}_{20}$ is largely influenced by the efficiency of the clotting enzyme due to milk acidity (Bonfatti et al., 2012b), effects of $\beta$-CN content on RCT and $\mathrm{K}_{20}$ were estimated also at constant milk acidity. Variation in RCT and $\mathrm{K}_{20}$ across $\beta$-CN content classes was less pronounced, but still relevant, when effects of milk $\mathrm{pH}$ were accounted for by the statistical model. The effect of $\beta$-CN content on BMCP has been studied in goat and cow milk, either in experimental or in field conditions, and general agreement exists on the favorable effect exerted by increased content of this protein on BMCP (Pearse et al.,
1986; Rampilli et al., 1988). Several properties explain the role of this protein fraction in variation of BMCP: (1) $\beta$-CN dissociates from the CN micelle with cooling and, when the cooled micelles are warmed again, the reassociation of $\beta$-CN may alter the structural features of the micelle surface (Dalgleish, 1998); (2) the C-terminal part of $\beta$-CN becomes adhesive at temperature $>4^{\circ} \mathrm{C}$, weakening the micelle stability (Fox and McSweeney, 2003 ); and (3) the hydrophilic moiety of $\beta-\mathrm{CN}$, containing phosphoryl groups, is directly involved in curd formation and coagulation fails to occur when more than $20 \%$ of $\beta-\mathrm{CN}$ is substituted by dephosphorylated $\beta-\mathrm{CN}$ (Jimenez-Flores and Richardson, 1988). Comparative analysis of coagulation properties of goat milk containing or not containing $\beta-\mathrm{CN}$ for the effect of a null allele at CSN2 evidenced that RCT of $\beta$-CN-lacking milk was 3 times longer than that of normal milk (Chianese et al., 1993). However, in a recent investigation (Remeuf et al., 2001), the association of increased $\beta-\mathrm{CN}$ content with favorable BMCP was not confirmed because of the tight linkage between the null allele at CSN2 and the high-type allele at $C S N 1 S 1$.

Variation in $\mathrm{A}_{30}$ associated with $\beta-\mathrm{CN}$ content was small. Previous studies on cow milk reported that increased contents of CN fractions were associated with increased $\mathrm{A}_{30}$ (Jõudo et al., 2008). Particularly, curd tension increased significantly with $\beta-\mathrm{CN}$ fortification 
Table 4. Estimate and $95 \%$ highest posterior density region (HPD95\%) of the effect of whey protein fraction content class relative to the intermediate class (PR0) on $\mathrm{pH}$, rennet-coagulation time (RCT), curd-firming time $\left(\mathrm{K}_{20}\right)$, and curd firmness $\left(\mathrm{A}_{30}\right)^{1}$

\begin{tabular}{|c|c|c|c|c|c|c|c|c|c|c|}
\hline \multirow{2}{*}{ Effect } & \multirow{2}{*}{ Trait } & \multicolumn{9}{|c|}{ Protein fraction class ${ }^{2}$} \\
\hline & & \multicolumn{2}{|c|}{$\mathrm{PR}--$} & \multicolumn{2}{|c|}{$\mathrm{PR}-$} & PR0 & \multicolumn{2}{|c|}{$\mathrm{PR}+$} & \multicolumn{2}{|c|}{$\mathrm{PR}++$} \\
\hline \multirow[t]{3}{*}{$\alpha-\mathrm{LA}$} & $\mathrm{pH}$ & 0.09 & -0.18 to 0.35 & -0.02 & -0.25 to 0.20 & 0 & 0.13 & -0.13 to 0.37 & 0.17 & -0.06 to 0.40 \\
\hline & $\mathrm{RCT}$ & $0.24^{\mathrm{a}}$ & -0.01 to 0.48 & $-0.02^{\mathrm{b}}$ & -0.23 to 0.19 & $0^{\mathrm{b}}$ & $0.10^{\mathrm{b}}$ & -0.14 to 0.33 & $0.06^{\mathrm{b}}$ & -0.15 to 0.28 \\
\hline & $\mathrm{K}_{20}$ & 0.17 & -0.10 to 0.44 & -0.07 & -0.30 to 0.17 & 0 & -0.05 & -0.31 to 0.20 & -0.01 & -0.24 to 0.23 \\
\hline \multirow{3}{*}{$\beta-\mathrm{LG}$} & $\mathrm{RCT}$ & $-0.12^{\mathrm{a}}$ & -0.36 to 0.12 & $0.06^{\mathrm{b}}$ & -0.16 to 0.28 & $0^{\mathrm{a}}$ & $0.17^{\mathrm{b}}$ & -0.04 to 0.38 & $0.27^{\mathrm{b}}$ & 0.06 to 0.51 \\
\hline & $\mathrm{K}_{20}$ & $-0.12^{\mathrm{a}}$ & -0.39 to 0.14 & $0.06^{\mathrm{ab}}$ & -0.19 to 0.29 & $0^{\mathrm{a}}$ & $0.15^{\mathrm{ab}}$ & -0.08 to 0.38 & $0.28^{\mathrm{b}}$ & 0.04 to 0.54 \\
\hline & $\mathrm{A}_{30}$ & -0.09 & -0.23 to 0.06 & -0.02 & -0.15 to 0.11 & 0 & -0.04 & -0.17 to 0.09 & -0.04 & -0.17 to 0.09 \\
\hline
\end{tabular}

\footnotetext{
${ }^{\mathrm{a}, \mathrm{b}}$ Estimates within a row with different superscripts have a posterior probability greater than $95 \%$ of being different.

${ }^{1}$ Magnitude of the estimates are expressed in standard deviation units of the trait.

${ }^{2}$ Whey protein fraction content was classified as follows: class PR $--($ content $<\bar{x}-\mathrm{SD})$, class $\mathrm{PR}-(\bar{x}-\mathrm{SD} \leq$ content $<\bar{x}-0.5 \mathrm{SD})$, class
} PR0 $(\bar{x}-0.5 \mathrm{SD} \leq$ content $<\bar{x}+0.5 \mathrm{SD})$, class $\mathrm{PR}+(\bar{x}+0.5 \mathrm{SD} \leq$ content $<\bar{x}+\mathrm{SD})$, and class $\mathrm{PR}++($ content $\geq \bar{x}+\mathrm{SD})$.

(Yun et al., 1982a,b) when Ca content was not a limiting resource for micelle formation (St-Gelais and Haché, 2005). The magnitude of $A_{30}$ variation depending upon differences in protein fraction contents detected in our study is inconsistent with findings of previous investigations. The unimportant effects of TCN and $\mathrm{CN}$ fraction contents on $\mathrm{A}_{30}$ might be partly explained by the very short RCT observed in this study. Because the time frame for the observation of coagulation is restricted to $31 \mathrm{~min}$, milk samples showing increased RCT have less time for curd firming and, thus, weaker curds than milk with short RCT. Because of the low average RCT, the time available for curd firming was greater in this investigation than in studies where delayed onset of coagulation was observed. Likely, this effect reduced the variability of $\mathrm{A}_{30}$ attributable to differences in protein fraction contents.

Content of $\alpha_{S 2}-C N, \gamma-C N$, and $\kappa-C N$. Among the $\mathrm{CN}$ fractions, $\alpha_{\mathrm{S}_{2}} \mathrm{CN}$ is the less studied and no information on its role in micelle formation or interac- tions with other protein fractions is available. In our study, the effects of $\alpha_{\mathrm{S}^{-}} \mathrm{CN}$ content classes on BMCP were unclear, but longer $\mathrm{K}_{20}$ and lower $\mathrm{A}_{30}$ were observed for class PR-- than for the other classes of this protein fraction.

For the dairy industry, an increased level of proteolysis is detrimental because it results in a marked decrease in the amount of intact CN (Somma et al., 2008). Proteolysis in milk occurs mainly by action of plasmin, which primarily hydrolyzes $\beta$-CN to $\gamma$-CN (Somma et al., 2008). The average content of $\gamma$-CN was very low in our samples, indicating that proteolysis was limited. This can explain the lack of association between the logarithmic transformation of $\gamma-\mathrm{CN}$ content and variation in BMCP detected in our study.

Unlike cow milk (Fox and McSweeney, 2003), RCT was shorter for milk exhibiting low $\kappa-\mathrm{CN}$ content, whereas $\mathrm{K}_{20}$ was not affected by variation in $\kappa-\mathrm{CN}$ content. These results may be ascribed to the great amount of this $\mathrm{CN}$ fraction in buffalo milk relative

Table 5. Estimate and 95\% highest posterior density region (HPD95\%) of the effect of glycosylated $\kappa$-CN content class relative to the intermediate class (PR0) on $\mathrm{pH}$, rennet-coagulation time (RCT), curd-firming time $\left(\mathrm{K}_{20}\right)$ and curd firmness $\left(\mathrm{A}_{30}\right)^{1}$

Protein fraction class ${ }^{2}$

\begin{tabular}{|c|c|c|c|c|c|c|c|c|c|}
\hline Trait & \multicolumn{2}{|c|}{$\mathrm{PR}--$} & \multicolumn{2}{|c|}{$\mathrm{PR}-$} & PR0 & \multicolumn{2}{|c|}{$\mathrm{PR}+$} & \multicolumn{2}{|c|}{$\mathrm{PR}++$} \\
\hline $\mathrm{pH}$ & 0.12 & -0.17 to 0.39 & 0.17 & -0.07 to 0.39 & 0 & 0.05 & -0.18 to 0.30 & -0.01 & -0.27 to 0.27 \\
\hline $\mathrm{K}_{20}$ & 0.22 & -0.07 to 0.51 & 0.18 & -0.07 to 0.41 & 0 & -0.07 & -0.32 to 0.18 & 0.01 & -0.26 to 0.29 \\
\hline $\mathrm{A}_{30}$ & -0.01 & -0.17 to 0.13 & 0.02 & -0.12 to 0.15 & 0 & -0.14 & -0.29 to 0.00 & 0.00 & -0.15 to 0.16 \\
\hline
\end{tabular}

${ }^{\mathrm{a}-\mathrm{C}}$ Estimates within a row with different superscripts have a posterior probability greater than $95 \%$ of being different.

${ }^{1}$ Magnitudes of the estimates are expressed in standard deviation units of the trait.

${ }^{2}$ Glycosylated $\kappa-\mathrm{CN}$ content was classified as follows: class PR $--($ content $<\bar{x}-\mathrm{SD})$, class $\mathrm{PR}-(\bar{x}-\mathrm{SD} \leq$ content $<\bar{x}-0.5 \mathrm{SD})$, class $\mathrm{PR} 0$ $(\bar{x}-0.5 \mathrm{SD} \leq$ content $<\bar{x}+0.5 \mathrm{SD})$, class $\mathrm{PR}+(\bar{x}+0.5 \mathrm{SD} \leq$ content $<\bar{x}+\mathrm{SD})$, and class $\mathrm{PR}++($ content $\geq \bar{x}+\mathrm{SD})$. 
Table 6. Estimate and 95\% highest posterior density region (HPD95\%) of the effect of CSN1S1-CSN3 genotypes relative to genotype BB-X2X2 on $\mathrm{pH}$, rennet-coagulation time $(\mathrm{RCT})$, curd-firming time $\left(\mathrm{K}_{20}\right)$, and curd firmness $\left(\mathrm{A}_{30}\right)^{1}$

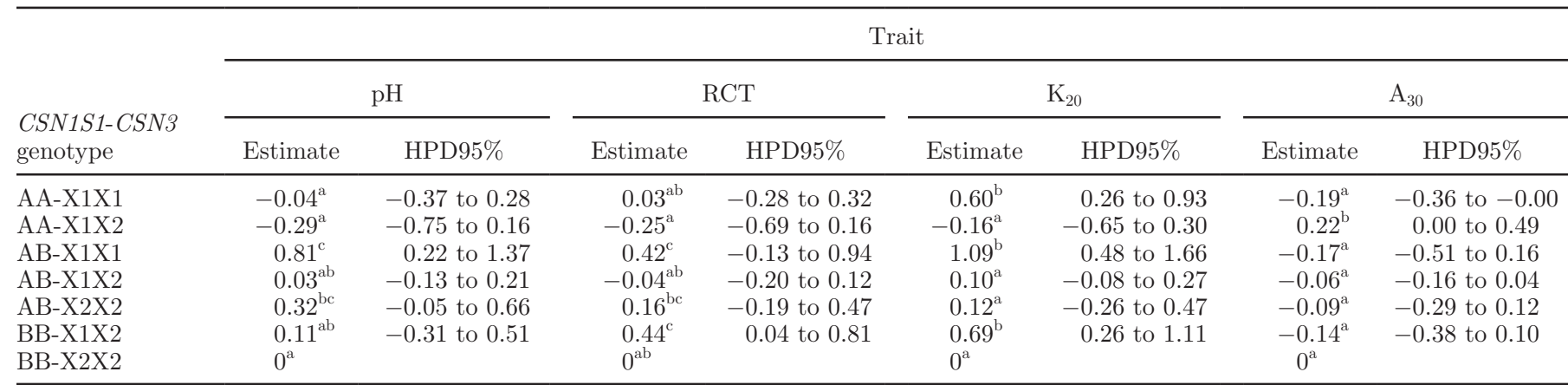

${ }^{a-c}$ Different superscript letters within a column indicate that the posterior probability of the difference between 2 genotypes being $>0$ (for positive differences) or $<0$ (for negative differences) was greater than $95 \%$.

${ }^{1}$ Magnitudes of the estimates are expressed in standard deviation units of the trait.

to that of cow milk, which seems to guarantee better conditions for the enzymatic phase of coagulation. In such conditions, the onset of gelation may be influenced to a greater extent by the aggregation properties of the other $\mathrm{CN}$ fractions than by the amount of $\kappa-\mathrm{CN}$ available for chymosin cleavage. The content of $\kappa-\mathrm{CN}$ was not associated with $\mathrm{A}_{30}$ variation, although general agreement exists in the literature on the favorable effect exerted by increased content of this fraction on $\mathrm{CN}$ retention in curd during chymosin-induced coagulation (Fox and McSweeney, 2003). Such an effect is the consequence of the association of low micelle diameter with increased $\kappa$-CN content, which, in turn, is related to an improved ability of the curd to entrap milk constituents. As previously stated, the lack of association between $\mathrm{\kappa}$-CN content and $\mathrm{A}_{30}$ observed in this study can be attributed to the very short RCT, which likely decreased the relative importance of differences in protein fraction contents for variability of $A_{30}$.

\section{Effect of the Amount of the Whey Protein Fractions on $\mathrm{pH}$ and $\mathrm{BMCP}$}

The estimated effects of the content of the 2 main whey protein fractions on BMCP are reported in Table 4. Coagulation was slightly faster for milk containing low amounts of $\beta$-LG than for milk with an increased content of $\beta$-LG. Low content of $\alpha$-LA was associated with a slightly longer RCT. Because the milk temperature before renneting did not reach that of $\beta$-LG denaturation, the interference carried out by the formation of $\beta$-LG- $\kappa-\mathrm{CN}$ aggregates on the renneting process (Considine et al., 2007) is to be excluded. Hence, the effects of $\beta$-LG content on BMCP, albeit of small magnitude, are difficult to interpret.

\section{Effect of the Content of Glycosylated $\mathrm{K}-\mathrm{CN}$ on BMCP}

The estimated effects of the content of glyco- $\kappa-\mathrm{CN}$ on BMCP are reported in Table 5. Rennet-coagulation time increased when the glyco- $\kappa-\mathrm{CN}$ content in milk increased, explaining the positive association between total $\kappa-C N$ and RCT. The RCT variation observed between the extreme classes of glyco- $\kappa-\mathrm{CN}$ content was equal to 0.59 standard deviation units of the trait. In agreement with results of our study, Addeo et al. (1984) observed that RCT of artificial micelles containing $\alpha_{\mathrm{S}^{-}}$, $\beta$-, and $\kappa_{-} \mathrm{CN}$ increased when the $\mathrm{N}$-acetylneuraminic acid content in $\kappa$-CN increased.

Glycosylated $\kappa-\mathrm{CN}$ is the protein fraction that protrudes from the surface of the micelle, providing $\mathrm{CN}$ stability in a colloidal state. Glycosidic moieties connected to the C-terminal fragment of $\kappa$ - $\mathrm{CN}$ enhance the ability of this protein to stabilize micelles and increase $\kappa$-CN resistance to proteolytic enzymes and high temperature in simple model systems (Dziuba and Minkiewicz, 1996). Hence, when the amount of glyco-к-CN in milk is high, chymosin might require additional time to determine the precipitation of the micelles.

\section{Effect of CSN1S1-CSN3 Composite Genotype on $\mathrm{pH}$ and BMCP}

The estimated effects of composite CSN1S1-CSN3 genotypes on BMCP are reported in Table 6 . Bonfatti et al. (2012b) presented estimates of CSN1S1-CSN3 genotypes effects on BMCP, using part of the data used in the current study and a model that did not account for variation in milk protein composition. Estimates of genotype effects obtained in the current study are consistent with estimates of Bonfatti et al. (2012b), indicating that 
genotype effects on BMCP cannot be entirely ascribed to the existing variation in milk protein composition associated with polymorphisms at CSN1S1 and CSN3 genes (Bonfatti et al., 2012c).

\section{CONCLUSIONS}

Results of this study indicate that protein composition affects variation in BMCP. Milk protein composition, namely the relative content of $\alpha_{\mathrm{S}^{-}} \mathrm{CN}$ and $\beta$-CN, affects RCT and $\mathrm{K}_{20}$. Although the role of the detailed milk protein composition in variation in cheese yield needs to be further investigated, findings from the present study suggest that modification of the relative content of specific fractions in TCN can relevantly influence the behavior of milk during processing. Previously detected differences across $\mathrm{CN}$ genotypes in relation to $\mathrm{BMCP}$ are not to be ascribed to the variation in milk protein composition associated with polymorphisms at CN genes. This suggests that other mechanisms need to be identified to elucidate the role of $\mathrm{CN}$ gene polymorphisms in variation in BMCP.

\section{ACKNOWLEDGMENTS}

Associazione Nazionale Allevatori Specie Bufalina (ANASB, Caserta, Italy) is gratefully acknowledged for having organized herd sampling and the supply of milk recording data. We thank Filippo Di Rubbo (ANASB) for having carried out collection of milk samples.

\section{REFERENCES}

Addeo, F., P. Martin, and B. Ribadeau-Dumas. 1984. Susceptibility of buffalo and cow $\kappa$-caseins to chymosin action. Milchwissenschaft 39:202-205.

Addeo, F., J.-P. Pelissier, and L. Chianese. 1980. Specific action of milk-clotting enzymes on water buffalo caseins. I. Effect of chymosin on $\beta$-casein. J. Dairy Res. 47:421-426.

Ambrosoli, R., L. Di Stasio, and P. Mazzocco. 1988. Content of $\alpha_{\mathrm{s} 1^{-}}$ casein and coagulation properties in goat milk. J. Dairy Sci. $71: 24-28$.

Ariota, B., G. Campanile, A. Potena, R. Napolano, B. Gasparrini, G. L. Neglia, and R. Di Palo. 2007. Ca and P in buffalo milk: Curd yield and milk clotting parameters. Ital. J. Anim. Sci. 6:497-499.

Ariota, B., L. Milone, C. Grassi, F. Zicarelli, R. Napolano, A. Giovane, and R. Di Palo. 2009. Milk protein and cheese yield in buffalo species. Ital. J. Anim. Sci. 8:381-383.

Bonfatti, V., A. Cecchinato, L. Gallo, A. Blasco, and P. Carnier. 2011. Genetic analysis of detailed milk protein composition and coagulation properties in Simmental cattle. J. Dairy Sci. 94:5183-5193.

Bonfatti, V., M. Gervaso, A. Coletta, and P. Carnier. 2012a. Effect of parity, days in milk, and milk yield on variation of detailed milk protein composition of Mediterranean water buffalo. J. Dairy Sci. 95:4223-4229.

Bonfatti, V., M. Giantin, M. Gervaso, A. Coletta, M. Dacasto, and P. Carnier. 2012b. Effect of CSN1S1-CSN3 ( $\alpha_{\mathrm{S}_{1}} \kappa$-casein) composite genotype on milk production traits and milk coagulation properties in Mediterranean water buffalo. J. Dairy Sci. 95:3435-3443.

Bonfatti, V., M. Giantin, R. Rostellato, A. Coletta, M. Dacasto, and P. Carnier. 2012c. Short communication: CSN1S1-CSN3 ( $\alpha_{S 1-} \kappa-$ casein) composite genotype affect detailed milk protein composition of Mediterranean water buffalo. J. Dairy Sci. 95:6801-6805.

Bonfatti, V., M. Giantin, R. Rostellato, M. Dacasto, and P. Carnier. 2013. Separation and quantification of water buffalo milk protein fractions and genetic variants by RP-HPLC. Food Chem. 136:364-367.

Bonfatti, V., L. Grigoletto, A. Cecchinato, L. Gallo, and P. Carnier. 2008. Validation of a new reversed-phase high-performance liquid chromatography method for separation and identification of bovine milk protein genetic variants. J. Chromatogr. A 1195:101-106.

Cecchinato, A., and P. Carnier. 2011. Short communication: Statistical models for the analysis of coagulation traits using coagulating and noncoagulating milk information. J. Dairy Sci. 94:4214-4219.

Cecchinato, A., M. Penasa, C. Cipolat Gotet, M. De Marchi, and G. Bittante. 2012. Short communication: Factors affecting coagulation properties of Mediterranean buffalo milk. J. Dairy Sci. 95:1709-1713.

Chianese, L., G. Garro, M. A. Nicolai, R. Mauriello, P. Ferranti, R. Pizzano, U. Cappuccio, P. Laezza, F. Addeo, L. Ramunno, A. Rando, and R. Rubino. 1993. The nature of $\beta$-casein heterogeneity in caprine milk. Lait 73:533-547.

Clark, S., and J. W. Sherbon. 2000. Alpha $\mathrm{s}_{\mathrm{1} 1}$-casein, milk composition and coagulation properties of goat milk. Small Rumin. Res. $38: 123-134$.

Considine, T., H. A. Patel, S. G. Anema, H. Singh, and L. K. Creamer. 2007. Interaction of milk proteins during heat hydrostatic pressure treatments-A review. Innov. Food Sci. Emerg. Technol. 8:1-23.

Dal Zotto, R., M. De Marchi, A. Cecchinato, M. Penasa, M. Cassandro, P. Carnier, L. Gallo, and G. Bittante. 2008. Reproducibility and repeatability of measures of milk coagulation properties and predictive ability of mid-infrared reflectance spectroscopy. J. Dairy Sci. 91:4103-4112.

Dalgleish, D. G. 1998. Casein micelles as colloids: Surface structures and stabilities. J. Dairy Sci. 81:3013-3018.

Dziuba, J., and P. Minkiewicz. 1996. Influence of glycosylation on micelle-stabilizing ability and biological properties of C-terminal fragments of cow's K-casein. Int. Dairy J. 6:1017-1044.

El-Shibiny, S., and M. H. Abd El-Salam. 1977. Action of milk clotting enzymes on $\alpha_{S^{-}}$-caseins from buffalo's and cow's milk. J. Dairy Sci. 60:1519-1521.

Fox, P. F., and P. L. H. McSweeney, editors. 2003. Advanced Dairy Chemistry: Volume 1: Proteins. Kluwer/Plenum, New York, NY.

Ikonen, T., S. Morri, A.-M. Tyrisevä, O. Ruottinen, and M. Ojala. 2004. Genetic and phenotypic correlations between milk coagulation properties, milk production traits, somatic cell count, casein content, and $\mathrm{pH}$ of milk. J. Dairy Sci. 87:458-467.

Jimenez-Flores, R., and T. Richardson. 1988. Genetic engineering of the caseins to modify the behavior of milk during processing: A review. J. Dairy Sci. 71:2640-2654.

Jõudo, I., M. Henno, T. Kaart, T. Püssa, and O. Kärt. 2008. The effect of milk protein contents on the rennet coagulation properties of milk from individual dairy cows. Int. Dairy Sci. 18:964-967.

Mariani, B. P., A. Summer, P. D. Di Gregorio, A. Randoe, E. Fossa, and M. Pecorari. 2001. Effects of the CSN1A(G) allele on the clotting time of cow milk and on the rheological properties of rennetcurd. J. Dairy Res. 68:63-70.

Parlato, E., and L. D. Van Vleck. 2012. Effect of parentage misidentification on estimates of genetic parameters for milk yield in the Mediterranean Italian buffalo population. J. Dairy Sci. 95:40594064 .

Pearse, M. J., P. M. Linklater, R. J. Hall, and A. G. Mackinlay. 1986. Effect of casein micelle composition and casein dephosphorylation on coagulation and syneresis. J. Dairy Res. 53:381-390.

Potena, A., C. De Filippo, D. Bove, T. Cocca, T. Haubner, and L. Zicarelli. 2001. Resa alla caseificazione e parametri reologici del latte bufalino: Risultati preliminari su latti individuali. Pages 236-240 in Proc. I Congr. Naz. sull'allevamento del buffalo, Eboli.

Potena, A., R. Napolano, G. Galiero, A. Coletta, R. Di Palo, G. Neglia, and L. Zicarelli. 2007. Relationship between lactodinamographic and characteristics of buffalo milk. Ital. J. Anim. Sci. 6:1084-1087. 
Rampilli, M., A. Caroli, P. Bolla, and G. Pirlo. 1988. Relazioni tra genotipi lattoproteici, composizione caseinica e attitudine alla coagulazione del latte nel corso della lattazione. Scienza e Tecnica Lattiero Casearia 39:262-279.

Raynal, K., and F. Remeuf. 2000. Effect of storage at $4{ }^{\circ} \mathrm{C}$ on the physicochemical and renneting properties of milk: A comparison of caprine, ovine and bovine milks. J. Dairy Res. 67:199-207.

Remeuf, F., G. Ricordeau, G. Brignon, and F. Grosclaude. 2001. Influence de la teneur en caséine $\beta$ sur les caractéristiques physicchimiques et l'aptitude à la coagulation enzymatique du lait de chèvre. Lait 81:731-742.

Rosati, A., and L. D. Van Vleck. 2002. Estimation of genetic parameters for milk, fat, protein and mozzarella cheese production for the Italian river buffalo Bubalus bubalis population. Livest. Prod. Sci. 74:185-190.

Somma, A., P. Ferranti, F. Addeo, R. Mauriello, and L. Chianese. 2008. Peptidomic approach based on combined capillary isoelectric focusing and mass spectrometry for the characterization of the plasmin primary products from bovine and water buffalo $\beta$-casein. J. Chromatogr. A 1192:294-300.
Sorensen, D., and D. Gianola. 2002. Likelihood, Bayesian, and MCMC Methods in Quantitative Genetics. Springer-Verlag, New York, NY.

St-Gelais, D., and S. Haché. 2005. Effect of $\beta$-casein concentration in cheese milk on rennet coagulation properties, cheese composition and cheese ripening. Food Res. Int. 38:523-531.

Wedholm, A., L. B. Larsen, H. Lindmark-Månsson, A. H. Karlsson, and A. Andrén. 2006. Effect of protein composition on the cheesemaking properties of milk from individual dairy cows. J. Dairy Sci. 89:3296-3305.

Yun, S. E., K. Ohmiya, and S. Shimizu. 1982a. Role of $\beta$-casein in milk curdling. Agric. Biol. Chem. 46:443-449.

Yun, S. E., K. Ohmiya, and S. Shimizu. 1982b. Role of the phosphoryl group of $\beta$-casein in milk curdling. Agric. Biol. Chem. 46:1505-1511.

Zicarelli, L. 2004. Buffalo milk: Its properties, dairy yield and Mozzarella production. Vet. Res. Commun. 28:127-135.

Table A1. Description of statistical models used in the study ${ }^{1}$

\begin{tabular}{|c|c|c|c|c|}
\hline Effect & Class & Model 1 & Model 2 & Model 3 \\
\hline Herd test day & 15 & Yes & Yes & Yes \\
\hline Parity $^{2}$ & 3 & Yes & Yes & Yes \\
\hline $\mathrm{DIM}^{3}$ & 5 & Yes & Yes & Yes \\
\hline CSN1S1-CSN3 genotype & 7 & Yes & Yes & Yes \\
\hline Renneting measuring well ${ }^{4}$ & 10 & Yes & Yes & Yes \\
\hline Casein content ${ }^{5}$ & 5 & Yes & No & No \\
\hline Whey protein content ${ }^{6}$ & 5 & Yes & No & No \\
\hline$\alpha_{\mathrm{S} 1}-\mathrm{CN}$ content & 5 & No & Yes & Yes \\
\hline$\alpha_{S^{2}-} \mathrm{CN}$ content & 5 & No & Yes & Yes \\
\hline$\beta-\mathrm{CN}$ content & 5 & No & Yes & Yes \\
\hline $\mathrm{L} \gamma-\mathrm{CN}$ content ${ }^{7}$ & 5 & No & Yes & Yes \\
\hline$\kappa-\mathrm{CN}$ content $^{8}$ & 5 & No & Yes & Yes \\
\hline Glycosylated $\kappa$-CN content & 5 & No & No & Yes \\
\hline$\alpha-L A$ content & 5 & No & Yes & Yes \\
\hline$\beta$-LG content & 5 & No & Yes & Yes \\
\hline
\end{tabular}

${ }^{1}$ Yes and no indicate whether the effect was included in the statistical model or not.

${ }^{2}$ Parity classes were defined as follows: class $1=$ first parity, class $2=$ from second to fourth parity, and class $3=$ parity greater than 4 .

${ }^{3}$ Days in milk classes were defined as follows: class $1=$ less than 60 DIM, class $2=$ from 60 to 159 DIM, class $3=$ from 160 to 219 DIM, class $4=$ from 220 to 279 DIM, and class $5=$ DIM 280 or greater.

${ }^{4}$ Renneting measuring well was included in the analysis of curd firmness only.

${ }^{5}$ Casein is the sum of $\alpha_{\mathrm{S}^{-}} \mathrm{CN}, \alpha_{\mathrm{S} 2^{-}} \mathrm{CN}, \beta-\mathrm{CN}, \gamma-\mathrm{CN}$, and $\kappa-\mathrm{CN}$ content.

${ }^{6}$ Whey protein is the sum of $\alpha$-LA and $\beta$-LG content.

${ }^{7} \mathrm{~L} \gamma-\mathrm{CN}=$ the logarithmic transformation of $\gamma-\mathrm{CN}$ content.

${ }^{8} \mathrm{k}-\mathrm{CN}=$ the sum of glycosylated $\kappa-\mathrm{CN}$ and unglycosylated $\kappa-\mathrm{CN}$ content; the content of each protein or group of proteins was classified as follows: class $\mathrm{PR}--($ content $<\bar{x}-\mathrm{SD})$, class $\mathrm{PR}-(\bar{x}-\mathrm{SD} \leq$ content $<\bar{x}-$ $0.5 \mathrm{SD})$, class PR0 $(\bar{x}-0.5 \mathrm{SD} \leq$ content $<\bar{x}+0.5 \mathrm{SD})$, class $\mathrm{PR}+(\bar{x}+0.5 \mathrm{SD} \leq$ content $<\bar{x}+\mathrm{SD})$, and class $\mathrm{PR}++($ content $\geq \bar{x}+\mathrm{SD})$; additional models also including milk $\mathrm{pH}$ were used to investigate whether the effects of protein composition detected with model 1,2 , or 3 on rennet-coagulation time, curd-firming time, and curd firmness were to be ascribed to variation in enzyme efficiency related to milk acidity. 